\title{
Health effects of exposure to diesel exhaust in diesel-powered trains
}

\author{
Maria Helena Guerra Andersen ${ }^{1,2^{*}}$ D, Marie Frederiksen², Anne Thoustrup Saber ${ }^{2}$, Regitze Sølling Wils ${ }^{1,2}$, \\ Ana Sofia Fonseca ${ }^{2}$, Ismo K. Koponen², Sandra Johannesson³ ${ }^{3}$, Martin Roursgaard', Steffen Loft ${ }^{1}$, Peter Møller ${ }^{1}$ and \\ Ulla Vogel l, $^{2,4}$
}

\begin{abstract}
Background: Short-term controlled exposure to diesel exhaust (DE) in chamber studies have shown mixed results on lung and systemic effects. There is a paucity of studies on well-characterized real-life DE exposure in humans. In the present study, 29 healthy volunteers were exposed to DE while sitting as passengers in diesel-powered trains. Exposure in electric trains was used as control scenario. Each train scenario consisted of three consecutive days (6 h/day) ending with biomarker samplings.

Results: Combustion-derived air pollutants were considerably higher in the passenger carriages of diesel trains compared with electric trains. The concentrations of black carbon and ultrafine particles were $8.5 \mu \mathrm{g} / \mathrm{m}^{3}$ and $1.2-$ $1.8 \times 10^{5}$ particles $/ \mathrm{cm}^{3}$ higher, respectively, in diesel as compared to electric trains. Net increases of $\mathrm{NOx}$ and $\mathrm{NO}_{2}$ concentrations were $317 \mu \mathrm{g} / \mathrm{m}^{3}$ and $36 \mu \mathrm{g} / \mathrm{m}^{3}$. Exposure to DE was associated with reduced lung function and increased levels of DNA strand breaks in peripheral blood mononuclear cells (PBMCs), whereas there were unaltered levels of oxidatively damaged DNA, soluble cell adhesion molecules, acute phase proteins in blood and urinary excretion of metabolites of polycyclic aromatic hydrocarbons. Also the microvascular function was unaltered. An increase in the low frequency of heart rate variability measures was observed, whereas time-domain measures were unaltered.
\end{abstract}

Conclusion: Exposure to DE inside diesel-powered trains for 3 days was associated with reduced lung function and systemic effects in terms of altered heart rate variability and increased levels of DNA strand breaks in PBMCs compared with electric trains.

Trial registration: ClinicalTrials.Gov (NCT03104387). Registered on March 23rd 2017

Keywords: Diesel exhaust, Train exposure, Lung function, Cardiovascular function, DNA damage, Comet assay

\section{Background}

Diesel exhaust (DE) exposure occurs in both environmental and occupational settings where engines are used for transportation or heavy-duty equipment for work processes. Exhaust from on-road vehicles is generally the most important source of DE in the urban environment, but emissions from diesel trains can also be an important local source of DE. The diesel trains do not only affect the DE levels in outdoor air, but also inside the

\footnotetext{
* Correspondence: mhar@sund.ku.dk; mga@nrcwe.dk

'Department of Public Health, Section of Environmental Health, University of Copenhagen, Øster Farimagsgade 5A, DK-1014 Copenhagen K, Denmark

${ }^{2}$ The National Research Centre for the Working Environment, Lersø Parkalle 105, DK-2100 Copenhagen $\varnothing$, Denmark

Full list of author information is available at the end of the article
}

trains since the plume may penetrate the train interior, which is a special problem when the locomotive pulls the train $[1,2]$. Accordingly, both the staff and commuters may be exposed to DE on a daily basis. Longterm exposure to $\mathrm{DE}$ is associated with increased risk of lung cancer $[3,4]$. In addition, traffic-generated air pollution is considered to be an important risk factor for cardiovascular diseases [5]. Although ultrafine particles (UFP) from diesel-powered vehicles are considered to be an important contributor to cardiovascular disease, it is difficult to separate this effect from other sources of particulate matter (PM) in urban air as diesel vehicles only contribute to $3-15 \%$ of the total $\mathrm{PM}_{2.5}$ mass [6].

(c) The Author(s). 2019 Open Access This article is distributed under the terms of the Creative Commons Attribution 4.0 International License (http://creativecommons.org/licenses/by/4.0/), which permits unrestricted use, distribution, and reproduction in any medium, provided you give appropriate credit to the original author(s) and the source, provide a link to the Creative Commons license, and indicate if changes were made. The Creative Commons Public Domain Dedication waiver (http://creativecommons.org/publicdomain/zero/1.0/) applies to the data made available in this article, unless otherwise stated. 
Oxidative stress and inflammation are considered important mechanisms of action for particle-generated cardiovascular diseases and cancer, with the latter also believed to be partially attributed to polycyclic aromatic hydrocarbons (PAHs) in the DE particle fraction as summarized in a recent review [7]. The review concludes that exposure to particles affects the vasomotor function, fibrinolysis system and heart rate variability (HRV). Particle exposure may affect the arterial blood vessels to increase vasoconstriction and reduce vasodilation [8]. The effect of DE has been investigated in a number of shortterm studies (i.e. few hours) where subjects were typically exposed in a chamber under controlled conditions. This has demonstrated reduced responsiveness to vasodilator-induced vasodilation [9-14], whereas HRV measurements have shown null or mixed results [15-18]. Lung function measurements have shown essentially null results [14, 19-25]. Effects on airways inflammation have consistently been observed in chamber studies $[21,23,24,26,27]$ with mixed results for systemic inflammation [9-11, 16, 18, 23, 25, 28-30]. In contrast to vascular, lung function and inflammation endpoints, only very few controlled DE exposure studies have included endpoints related to genotoxicity. To the best of our knowledge only one study has assessed DNA strand breaks and oxidatively damaged DNA in humans after controlled DE exposure in a chamber study and this showed no effect [31]. The same endpoints, measured by the alkaline comet assay, are standard genotoxicity tests in particle toxicology and molecular epidemiology on air pollution exposures [32].

The present study investigated real-life exposure to DE in diesel-powered trains. The commuter railway system in the greater Copenhagen area, Denmark, consists of both electric and diesel trains. Some of the diesel trains are relatively old (from the 1980s) and have rather high emission rates of PM. In addition, the DE plume from the locomotive penetrates to the interior of the passenger carriages, giving rise to high particle exposure as demonstrated by net increases of $\mathrm{PM}_{2.5}\left(36 \mu \mathrm{g} / \mathrm{m}^{3}\right)$, UFP $\left(2 \times 10^{5}\right.$ particles $\left./ \mathrm{cm}^{3}\right)$ and black carbon $\left(8.3 \mu \mathrm{g} / \mathrm{m}^{3}\right)$ compared to the concentrations in electric trains [33]. The high particle concentration in diesel-powered trains has caused concerns about possible long-term health effects of train staff and commuters. In order to investigate the effect of real-life DE exposure, 29 volunteers were recruited to participate in scenarios involving staying inside the first passenger carriage of regional trains $6 \mathrm{~h} /$ day for 3 consecutive days. Each volunteer was scheduled for two scenarios in diesel trains and one scenario in an electric train. The study design and the duration of the exposure were overall similar to, and inspired by a previous study on particle exposure in firefighters, which demonstrated elevated levels of PAH metabolites in urine, decreased microvascular function and increased levels of DNA damage in peripheral blood mononuclear cells (PBMCs) in conscripts immediately after a 3 day training course in firefighting as compared to 2 weeks before and 2 weeks after [34, 35]. The biomarkers included lung function, microvascular function, HRV and systemic levels of acute phase proteins and cell adhesion molecules, DNA damage in PBMCs and urinary excretion of PAH metabolites.

\section{Results \\ Exposure characterization}

In total, there were 54 and 29 person scenarios of exposure in diesel and electric trains, respectively. The exposure assessment showed a clear contrast in exposure levels between diesel and electric scenarios for concentrations of black carbon, UFP and nitrogen oxides (Table 1). The average concentrations of UFP were 15 to 23 fold higher in diesel trains, measured with NanoTracer and DiscMini portable devices, respectively. All the air pollution components were highly correlated (Fig. 1). More details on the exposure assessment and results can be found elsewhere [33].

\section{Association between train scenarios and biomarkers}

Table 2 presents the estimated effect of diesel exposure on the assessed biomarkers as compared to electric trains. The lung function measurements included forced vital capacity (FVC), forced expiratory volume after $1 \mathrm{~s}$ (FEV1) and peak expiratory flow (PEF). FEV1 and PEF showed a small but significant decrease after exposure to DE. Figure 2 shows the individual results for the lung function measurements; the mean biomarker level of two measurements is shown.

The microvascular function was measured by reactive hyperemia, using EndoPAT, and reported as the logarithmically transformed data (Ln.RHI). Neither this, nor nitroglycerin-induced vasodilation differed between the exposure scenarios, indicating a lack of detectable effect on endothelial-dependent and endothelial-independent vasomotor responses. As expected the nitroglycerininduced vasodilation was larger (2.2) than the reactive hyperemia-mediated vasodilation (i.e. 1.7, back-transformed from Ln.RHI $=0.57$ ). The only significant change in HRV measurements was an increase in the low frequencydomain component (LF) (Fig. 3), whereas time-domain components were unaffected.

DE exposure was associated with increased level of DNA strand breaks in PBMCs (Fig. 4), whereas the level of formamidopyrimidine DNA glycosylase (Fpg)- sensitive sites was unaffected by exposure. Markers of systemic acute phase proteins and soluble adhesion molecules were unaffected by exposure. 
Table 1 Black carbon, ultrafine particles and nitrogen oxides concentrations and contrast between diesel and electric trains

\begin{tabular}{llll}
\hline Exposure & Electric $(n=29)$ & Diesel $(n=54)$ & Mean difference $(95 \% \mathrm{Cl})$ \\
\hline Black carbon $\left(\mu \mathrm{g} / \mathrm{m}^{3}\right)$ & $1.8(0.5)$ & $10.3(2.0)$ & $8.5(7.9 ; 9.1)^{* * *}$ \\
Ultrafine particles from DiscMini $\left(\# / \mathrm{cm}^{3}\right)^{a)}$ & $8100(2400)$ & $189,200(91,900)$ & $181,000(153,700 ; 208,400)^{* * *}$ \\
Ultrafine particles from NanoTracer $\left(\# / \mathrm{cm}^{3}\right)$ & $9100(3500)$ & $133,400(52,100)$ & $124,300(110,000 ; 138,500)^{* * *}$ \\
$\mathrm{NOx}\left(\mu \mathrm{g} / \mathrm{m}^{3}\right)$ & $45(16)$ & $363(73)$ & $317(297 ; 338)^{* * *}$ \\
$\mathrm{NO}_{2}\left(\mu \mathrm{g} / \mathrm{m}^{3}\right)$ & $18(9)$ & $54(16)$ & $36(31 ; 42)^{* * *}$ \\
\hline
\end{tabular}

The exposure was assigned to study participants (study participants rode the trains in groups of different sizes. The exposure average levels for each calendar day were assigned to all members of the relevant group). Exposure levels in both scenarios are presented as mean and standard deviation. $\mathrm{PM}_{2.5}$, polycyclic aromatic hydrocarbons and aldehydes are not assigned to study participants, as the data were not collected throughout all the study period. ${ }^{\text {a) }}$ missing values for DiscMini equipment indexed to four study persons for the exposure scenarios ( $n=46$ diesel and $n=25$ for electric). ${ }^{* * *} p<0.001$

There was no exposure-related effect on urinary excretion of PAH metabolites used as biomarkers of exposure. The background levels (from electric scenario) of the creatinine adjusted PAHs showed large variation across individual subjects, from below the limit of quantification to $0.377 \mu \mathrm{mol} / \mathrm{mol}$ creatinine for 1-hydroxypyrene (1-OHP), 0.012 to $0.278 \mu \mathrm{mol} / \mathrm{mol}$ creatinine for 2-hydroxyfluorene (2-OHF), 0.117 to $2.55 \mu \mathrm{mol} / \mathrm{mol}$ creatinine for 1 naphthol (1-NAPH) and 0.283 to $10.6 \mu \mathrm{mol} / \mathrm{mol}$ creatinine for 2-naphthol (2-NAPH), respectively.

\section{Association between air pollution components and biomarker levels}

In the second step of the analysis, biomarkers that were statistically significant or with borderline statistical significance (defined as $0.05>P<0.10$ ) different for the two exposures scenarios were subsequently included in tests for association between individual air pollution components and biomarkers. Table 3 shows the direction of associations between exposure levels (UFP, BC and nitrogen oxides) and effects on biomarkers that showed

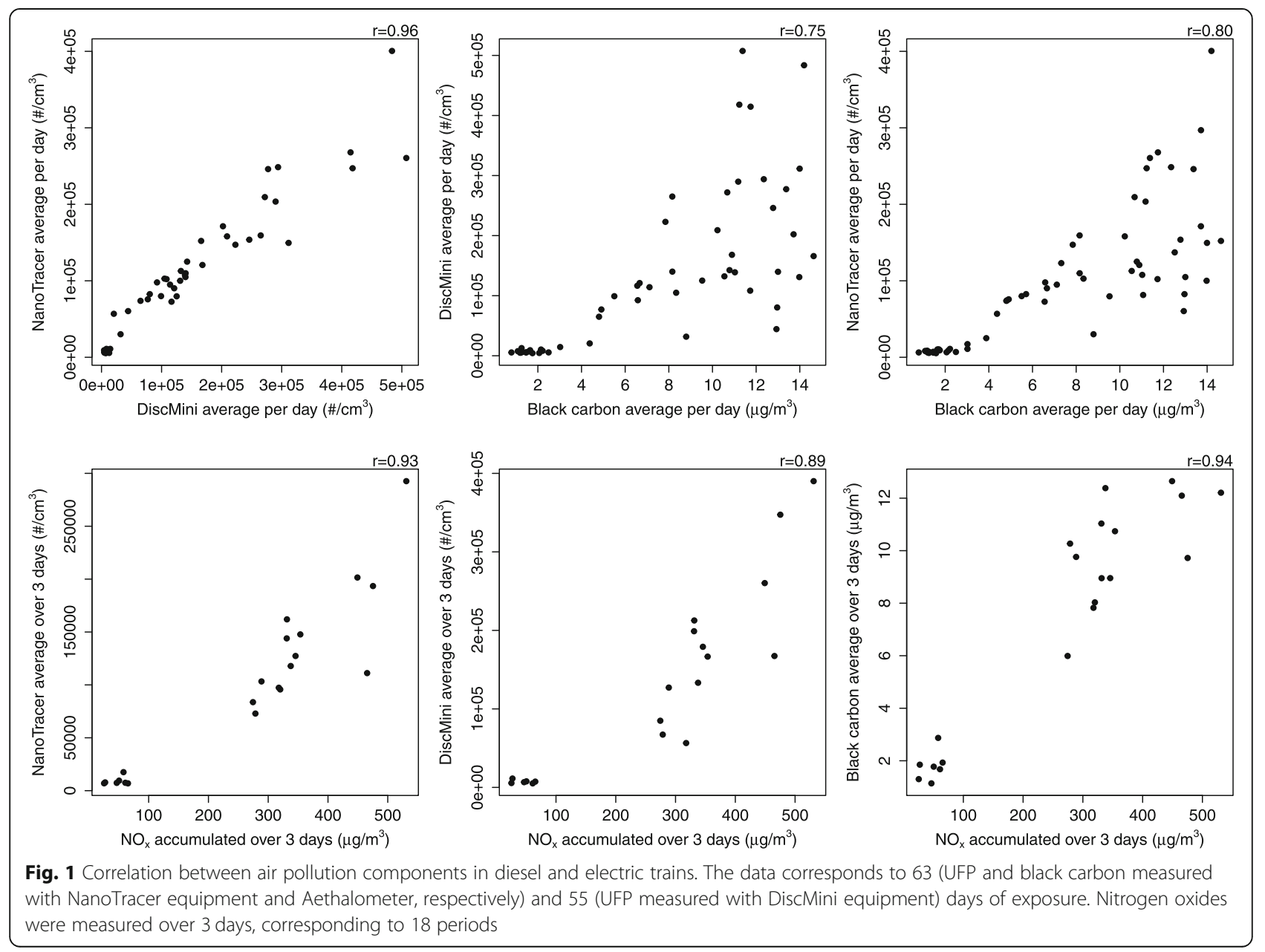


Table 2 Outcome levels for electric and diesel scenarios and percent changes in biomarker levels

\begin{tabular}{|c|c|c|c|c|c|}
\hline \multicolumn{2}{|l|}{ Biomarker } & \multirow{2}{*}{$\frac{\text { Electric (mean } \pm \mathrm{SD} \text { ) }}{0.049 \pm 0.083}$} & \multirow{2}{*}{$\begin{array}{l}\text { Diesel }(\text { mean } \pm \text { SD }) \\
0.027 \pm 0.019\end{array}$} & \multirow{2}{*}{$\begin{array}{l}\text { \% Change }(95 \% \mathrm{Cl}) \\
-12.2(-32.3 ; 14.0)\end{array}$} & \multirow{2}{*}{$\frac{p \text {-value }}{0.331}$} \\
\hline Urinary excretion & 1-OHP ( $\mu \mathrm{mol} / \mathrm{mol}$ creatinine) & & & & \\
\hline & 2-OHF ( $\mu \mathrm{mol} / \mathrm{mol}$ creatinine) & $0.075 \pm 0.067$ & $0.070 \pm 0.061$ & $0.6(-17.3 ; 22.4)$ & 0.952 \\
\hline & 1-NAPH ( $\mu \mathrm{mol} / \mathrm{mol}$ creatinine) & $0.851 \pm 0.603$ & $0.671 \pm 0.560$ & $-20.0(-44.3 ; 4.3)$ & 0.107 \\
\hline & 2-NAPH ( $\mu \mathrm{mol} / \mathrm{mol}$ creatinine) & $2.084 \pm 2.272$ & $1.861 \pm 1.679$ & $-0.4(-20.7 ; 25.2)$ & 0.975 \\
\hline \multirow[t]{4}{*}{ Lung function } & FVC (L) & $4.20 \pm 1.24$ & $4.18 \pm 1.16$ & $-2.3(-4.7 ; 0.25)$ & 0.077 \\
\hline & FEV1 (L) & $3.32 \pm 0.96$ & $3.24 \pm 0.96$ & $-3.6(-5.5 ;-1.6)$ & $0.0003^{* * *}$ \\
\hline & FEV1/FVC (\%) & $79.1 \pm 6.8$ & $77.2 \pm 9.2$ & $-1.8(-3.8 ; 0.2)$ & 0.073 \\
\hline & $\operatorname{PEF}(L / s)$ & $7.26 \pm 2.13$ & $7.15 \pm 2.42$ & $-5.6(-10.7 ;-0.5)$ & $0.031^{*}$ \\
\hline \multirow[t]{11}{*}{ Cardiovascular function } & Ln.RHI & $0.57 \pm 0.25$ & $0.55 \pm 0.28$ & $-1.4(-26.5 ; 23.7)$ & 0.913 \\
\hline & NIV & $2.26 \pm 1.06$ & $2.21 \pm 0.71$ & $-3.7(-34.6 ; 27.3)$ & 0.817 \\
\hline & pNN50 (\%) & $0.06 \pm 0.08$ & $6.54 \pm 0.07$ & $4.6(-13.8 ; 23.0)$ & 0.626 \\
\hline & RMSSD (ms) & $41.84 \pm 30.93$ & $36.39 \pm 19.02$ & $-3.5(-22.1 ; 19.7)$ & 0.326 \\
\hline & SDNN (ms) & $48.16 \pm 24.29$ & $44.24 \pm 16.76$ & $-2.1(-14.9 ; 12.7)$ & 0.773 \\
\hline & $\operatorname{LF}\left(m s^{2}\right)$ & $160.2 \pm 59.5$ & $195.9 \pm 78.8$ & $16.5(5.9 ; 27.0)$ & $0.002^{* *}$ \\
\hline & $\mathrm{HF}\left(\mathrm{ms}^{2}\right)$ & $153.6 \pm 57.6$ & $151.8 \pm 67.5$ & $2.0(-7.5 ; 11.5)$ & 0.681 \\
\hline & LF/HF & $1.27 \pm 0.83$ & $1.70 \pm 1.37$ & $18.5(-5.5 ; 48.6)$ & 0.141 \\
\hline & Al normalized to heart rate of 75 bpm (\%) & $-8.26 \pm 11.79$ & $-6.26 \pm 14.68$ & $1.6(-2.2 ; 5.5)$ & 0.405 \\
\hline & $\mathrm{DP}(\mathrm{mm} \mathrm{Hg})$ & $81.2 \pm 11.4$ & $82.3 \pm 10.8$ & $1.2(-2.9 ; 5.2)$ & 0.566 \\
\hline & $\mathrm{SP}(\mathrm{mm} \mathrm{Hg})$ & $135.1 \pm 16.1$ & $134.4 \pm 17.9$ & $-1.0(-4.9 ; 2.9)$ & 0.630 \\
\hline \multirow[t]{2}{*}{ DNA damage } & SB (lesions/10 bp) & $0.12 \pm 0.13$ & $0.18 \pm 0.13$ & $46.3(5.0 ; 100.9)$ & $0.025^{*}$ \\
\hline & Fpg-sensitive sites (lesions/10 bp) & $0.62 \pm 0.15$ & $0.58 \pm 0.12$ & $-5.0(-11.1 ; 1.1)$ & 0.109 \\
\hline \multirow[t]{2}{*}{ Adhesion molecules } & ICAM-1 (ng/mL) & $35.04 \pm 7.28$ & $34.34 \pm 6.88$ & $-2.5(-8.3 ; 3.7)$ & 0.426 \\
\hline & VCAM-1 (ng/mL) & $134.2 \pm 36.2$ & $129.6 \pm 35.8$ & $-3.2(-10.5 ; 4.7)$ & 0.416 \\
\hline \multirow[t]{2}{*}{ Acute phase proteins } & $\mathrm{SAA}(\mathrm{mg} / \mathrm{L})$ & $32.09 \pm 41.51$ & $36.46 \pm 47.35$ & $11.1(-17.8 ; 50.2)$ & 0.493 \\
\hline & CRP (mg/L) & $1.83 \pm 2.29$ & $1.90 \pm 2.48$ & $-12.3(-47.5 ; 46.4)$ & 0.615 \\
\hline
\end{tabular}

Percent change was estimated by mixed-effects model adjusted for age and sex, comparing diesel with electric scenarios

$\mathrm{Cl}$ confidence interval, SD standard deviation, 1-OHP 1-hydroxypyrene, 2-OHF 2-hydroxyfluorene, 1-NAPH 1-naphthol, 2-NAPH 2-naphthol, FVC forced vital capacity, FEV1 forced expiratory volume in one second, PEF peak expiratory flow rate, Ln.RHI reactive hyperemia index with natural logarithmic transformation (the percent change was back transformed), NIV nitroglycerin-induced vasodilation, pNN50 proportion of successive NN intervals differing by more than 50 milliseconds divided by total number of NN intervals, RMSSD square root of the mean squared differences of successive NN intervals, SDNN standard deviation of all NN intervals, $L F$ low frequency component $(0.04-0.15 \mathrm{~Hz}), H F$ high frequency component $(0.15-0.4 \mathrm{~Hz}), A /$ augmentation index, $D P$ diastolic blood pressure, $S P$ systolic blood pressure, SB DNA strand breaks, ICAM-1 intercellular cell adhesion molecule-1, VCAM-1 vascular cell adhesion molecule-1, SAA serum amyloid A, CRP C-reactive protein; ${ }^{*} p<0.05 ;{ }^{* *} p<0.01 ;{ }^{* * *} p<0.001$

statistical or borderline statistical significance in the overall test for effect for diesel versus electric trains. Overall, the measurements of lung function were inversely associated with levels of particles and nitrogen oxide levels. Likewise, LF and DNA strand breaks were positively associated with both particles and nitrogen oxides.

Table 4 presents the association between each of the 3 days exposure levels from direct-reading instruments and effects assessed on biomarkers sampled on day 3, at the end of the exposure scenario, estimated for the biomarkers that showed statistically or borderline statistical significance in the overall test for effect for diesel versus electric trains. There were no consistent trends between exposure (UFP and BC) and outcomes.

\section{Discussion}

This study shows that DE exposure in carriages of diesel-powered trains, for $6 \mathrm{~h}$ per day for three consecutive days, was sufficient to cause a reduction of lung function and systemic effects in terms of altered heart rate variability and increased levels of DNA strand breaks in PBMCs in healthy volunteers.

The reduction in lung function after DE exposure although small was remarkably consistent between the subjects. Nevertheless, the study participants could not be blinded for the exposure, which could potentially influence their effort in the spirometry performance. This is an unavoidable study limitation. We minimized this potential bias through the study design, which included a repetition of the diesel scenario, and 21-day wash out periods. It was not possible to separate the acute and 

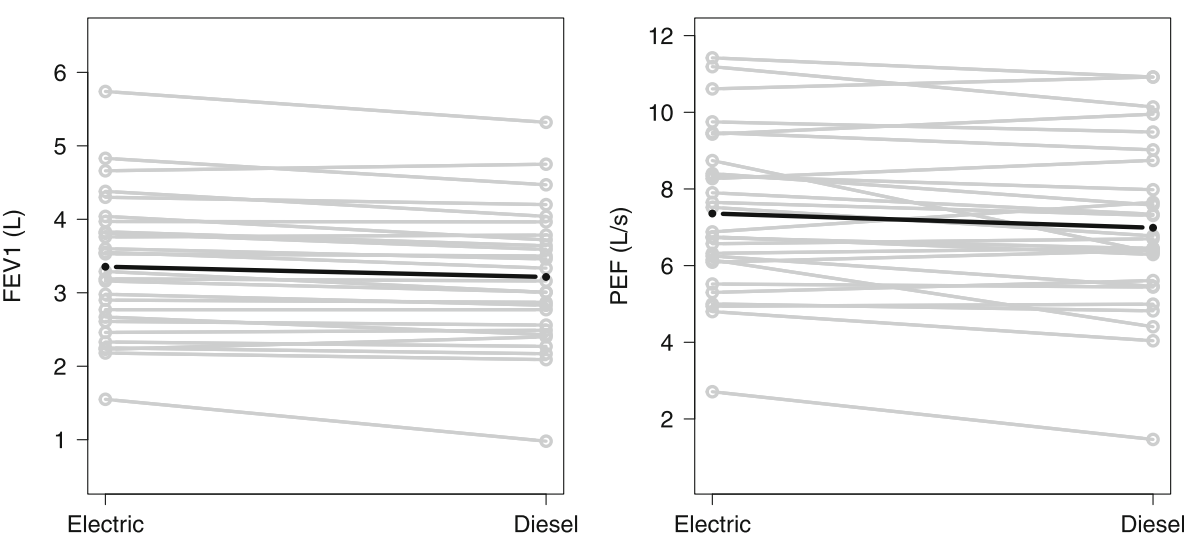

Fig. 2 Lung function parameters after exposure in electric and diesel trains. The circles in grey represent individual lung function parameters for electric train (one exposure scenario) or diesel train (mean of two exposure scenarios). The dark line represents the mixed-effects model without adjustments. Lower levels of FEV1 and PEF were observed on group level (solid symbols) after exposure in diesel trains $(p<0.05)$

late effects of DE exposure in the present study where exposure was repeated for three consecutive days before measurement of biomarkers. Similar associations between lung function measures and $\mathrm{NO}_{\mathrm{X}}$ gases and particles were found, indicating that effects of specific DE constituents cannot be differentiated in the current study. A study showed that DE exposure $\left(300 \mu \mathrm{g} / \mathrm{m}^{3}\right.$ for $2 \mathrm{~h}$ ) had no immediate effect on the lung function, whereas there was a stronger decline in ozone-mediated $(300 \mathrm{ppb})$ FEV1 in the DE exposed group as compared to filtered air the day after the exposure [20]. Other studies on short-term exposure to DE have not

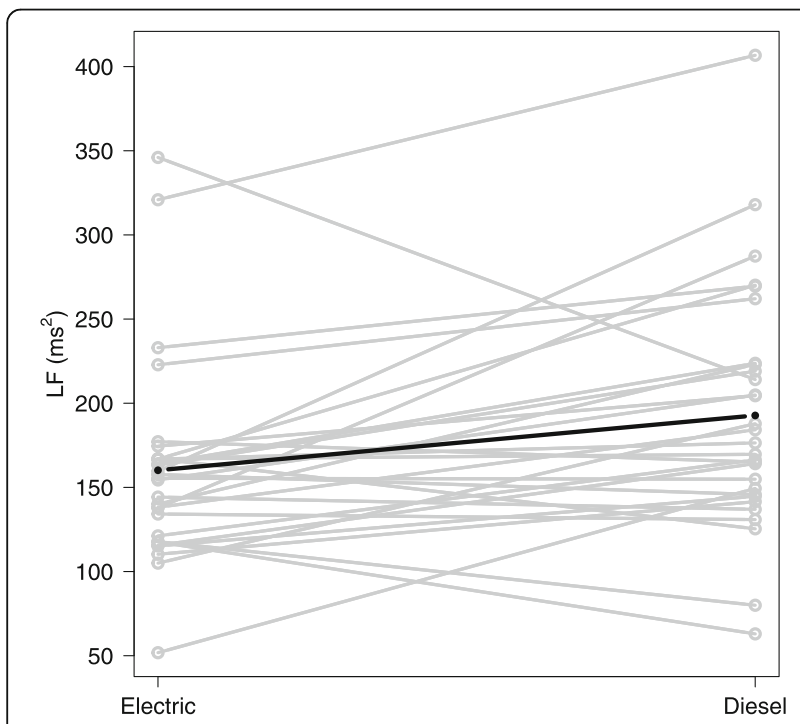

Fig. 3 Low frequency (LF) component of heart rate variability measured after exposure in electric and diesel trains. The circles in grey represent LF measurements in electric train (one exposure scenario) or diesel train (mean of two exposure scenarios). The dark line represents the mixedeffects model without adjustments. Higher LF levels were observed on group level (solid symbols) after exposure in diesel trains $(p<0.05)$ demonstrated effects on FEV1 in humans [14, 19-25], whereas one study showed reduced PEF starting at 75 min after the exposure [25]. PEF is reduced as a result of obstruction in the airways, which is seen in asthma patients. In addition to a reduced PEF in our study, there were reduced FEV1 and FVC and a near-normal FEV1/ FVC ratio. Reduction of both FEV1 and FVC, and unaltered FEV1/FVC ratio is typically observed in restrictive lung diseases, including fibrosis. However, the current exposure is too short for inducing fibrosis and it is more likely that the DE exposure affected the lung

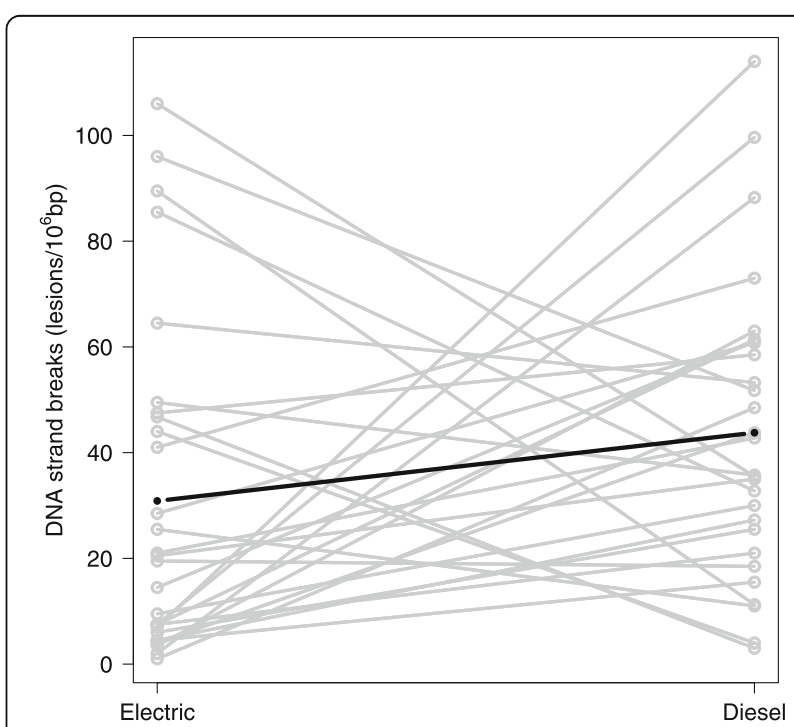

Fig. 4 DNA strand breaks in peripheral blood mononuclear cells after exposure in electric and diesel trains. The circles in grey represent DNA strand breaks in electric train (one exposure scenario) or diesel train (mean of two exposure scenarios). The dark line represents the mixedeffects model without adjustments. Higher levels of DNA strand breaks were observed on group level (solid symbols) after exposure in diesel trains $(p<0.05)$ 
Table 3 Association between exposure levels and biomarkers estimated by mixed-effects model adjusted for age and sex

\begin{tabular}{|c|c|c|c|c|c|c|}
\hline $\begin{array}{c}\text { Exposure } \\
\text { levels }\end{array}$ & FVC & FEV1 & FEV1/FVC & PEF & LF & DNA SB \\
\hline $\begin{array}{c}\text { UFP } \\
\text { (NanoTracer) }\end{array}$ & $\downarrow$ & $\downarrow \downarrow \downarrow$ & $\downarrow$ & $\downarrow$ & & \\
\hline $\begin{array}{c}\text { UFP } \\
\text { (DiscMini) }\end{array}$ & - & & - & & & \\
\hline $\mathrm{BC}$ & $\downarrow$ & $\downarrow \downarrow \downarrow$ & $\downarrow$ & $\downarrow$ & & \\
\hline $\mathrm{NO}_{\mathrm{x}}$ & $\downarrow$ & $\downarrow \downarrow \downarrow$ & $\downarrow$ & $\downarrow \downarrow$ & & \\
\hline $\mathrm{NO}_{2}$ & $\downarrow$ & $\downarrow$ & - & & & - \\
\hline
\end{tabular}

Exposure levels are averages of 3 days

UFP ultrafine particles, $B C$ black carbon, FVC forced vital capacity, FEV1 forced expiratory volume in one second, $P E F$ peak expiratory flow rate, $L F$ low frequency component, DNA SB DNA strand breaks

$\downarrow \downarrow^{\prime} \downarrow \downarrow \downarrow \downarrow \downarrow \downarrow p \leq 0.08 ;<0.05 ;<0.01 ;<0.001$, respectively

compliance towards decreased ability to expand. This effect could be reversible, although recurrent exposures may have a long-term effect on the lung function.

In the present study, there was unaltered vasomotor function and no effect on systemic levels of acute phase proteins (CRP and SAA). Low-grade systemic inflammation is an integrated part of the suggested mechanism of action of particle-generated toxicity in secondary tissues or cells [7]. It can be speculated that the exposure levels in the current study may not be sufficiently high to induce an acute phase response. There was no effect of $\mathrm{DE}$ exposure on vasomotor function in the current study. Other short-term controlled exposures to DE have yielded conflicting results in vasomotor function; blunted vasodilator-induced forearm blood flow in certain studies [9-11] and skin microvascular dysfunction [13]. Studies using flow-mediated vasodilation or reactive hyperemia by EndoPAT have shown unaltered vasomotor function [18, 36, 37]. Interestingly, certain studies have also reported increased vasoconstriction in DE exposed humans $[18,37,38]$. The available results may indicate a decreased sensitivity of vasodilator-induced forearm blood flow, although it should also be noted that the diesel fuels and engine types differ between studies. Our previous studies have indicated that exposure to PM from combustion processes were associated with microvascular dysfunction in elderly subjects [39-43], whereas no effects have been observed in young subjects [44, 45]. The wide age span in the present study might have diluted the effect on vasodilation due to inclusion of young subjects who may not be as susceptible to DE-induced vasomotor dysfunction. However, it should also be noted that a meta-analysis from controlled exposures in animal models indicates that DE (or DEP) exposure produces less effect on vasomotor responses as compared to outdoor air pollution particles and nanoparticles [46]. In contrast to the unaltered vasomotor function, we observed effects in the frequency-domain of HRV (16.5\% increase in LF and a statistically nonsignificant $18.5 \%$ increase in LF/HF ratio) that suggests a minor increase in sympathetic to vagal activity [47]. This is consistent with our previous finding of increased LFn after 5 -h exposure to street air in elderly slightly overweight subjects [43]. In contrast, a study with controlled DE exposure at $206 \mu \mathrm{g} / \mathrm{m}^{3}$ for $2 \mathrm{~h}$ showed a transient alteration in frequency domain outcomes in terms of increased HF and decreased LF/HF ratio at $3 \mathrm{~h}$ post exposure [17]). Two other studies have found unaltered HRV in subjects after short-term controlled DE exposure $[15,16]$.

We observed increased levels of DNA strand breaks after exposure to $\mathrm{DE}$, whereas there were unaltered levels of DNA oxidation lesions in the same PBMCs. In a previous study on controlled DE exposure $\left(276 \mu \mathrm{g} / \mathrm{m}^{3}\right.$ for $3 \mathrm{~h}$ ) we observed no effect on these endpoints immediately after exposure [31]. However, a controlled exposure study on traffic-generated air pollution showed a positive association between personal particle number concentration of especially size modes 23 and $57 \mathrm{~nm}$, 


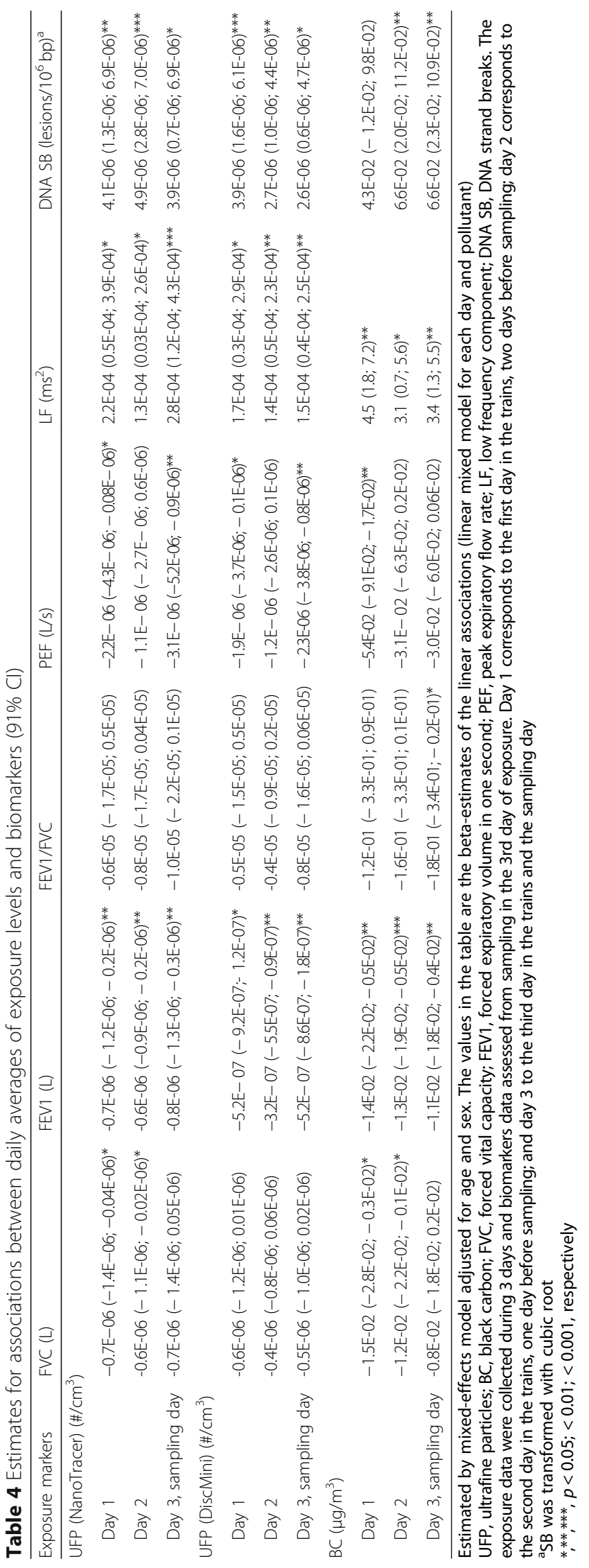


with high deposition fractions, and levels of Fpgsensitive sites in PBMCs [48]. Personal exposure to UFP, obtained by bicycling in streets with heavy traffic, was positively associated with levels of Fpg-sensitive sites in PBMCs, whereas there was no effect on levels of DNA strand breaks [49]. On the other hand, elderly and overweight subjects had unaltered levels of DNA strand breaks and Fpg-sensitive sites after exposure to urban street air in a controlled exposure study, whereas the total number of DNA lesions was positively associated with the particle number concentration [50]. Studies on high-dose exposure in animals have demonstrated mixed results for the association between pulmonary exposure to DEP and DNA strand breaks in lung tissue with certain studies showing increased levels of DNA damage [51-53] and no effect [54-56]. The literature on oxidatively damaged guanine lesions is partly flawed by studies that have used non-optimal techniques for measurements of 8-oxodG due to unspecific detection or spurious oxidation of DNA during the processing of samples [57]. Two studies on OGG1- or Fpg-sensitive sites, measured by the comet assay have shown unaltered levels of oxidatively damaged DNA in lung tissue at $24 \mathrm{~h}$ after i.t. instillation [55, 56]. A study on repeated inhalation $\left(20 \mathrm{mg} / \mathrm{m}^{3}\right.$ for $1.5 \mathrm{~h}$ on 4 consecutive days) showed unaltered levels of Fpg-sensitive sites and 8oxodG in lung tissue of wild-type mice [54]. Interestingly, a previous study had shown that a single inhalation exposure to $80 \mathrm{mg} / \mathrm{m}^{3}$ of DEP increased the levels of 8-oxodG in mice, whereas the same total administered dose on four consecutive days increased the expression of OGG1 accompanied by unaltered levels of 8oxodG [58]. This indicated that a high bolus exposure may saturate the DNA repair system, whereas the oxidative damage to DNA can be efficiently removed when DEP is administered in multiple lower doses.

The contrast between exposure levels in passenger carriages of diesel driven trains and electric trains in the present study is clear, as indicated by the net average difference of $8.5 \mu \mathrm{g} / \mathrm{m}^{3}$ in BC (6-fold), $1.2 \times 10^{5}-1.8 \times 10^{5}$ particles $/ \mathrm{cm}^{3}$ (15-24 fold) and $36 \mu \mathrm{g} / \mathrm{m}^{3} \mathrm{NO}_{2}$ (3-fold) during the $6 \mathrm{~h}$ exposure periods. In addition, the average difference in $\mathrm{PM}_{2.5}$ concentration between diesel and electric trains was $36 \mu \mathrm{g} / \mathrm{m}^{3}$ [33]. Previous studies on controlled DE exposure have used PM concentrations up to $300 \mu \mathrm{g} / \mathrm{m}^{3}$ for $1-3 \mathrm{~h}$ in chambers [19-21, 23, 25]. The time-integrated exposure in the present study $\left(216 \mu \mathrm{g}^{*} \mathrm{~h} / \mathrm{m}^{3}\right.$ per day or $648 \mu \mathrm{g}^{*} \mathrm{~h} / \mathrm{m}^{3}$ per 3-day exposure period) is similar to previous studies $\left(300-900 \mu \mathrm{g}^{*} \mathrm{~h} / \mathrm{m}^{3}\right)$. We have previously reported a contrast in the levels of particulate PAHs, but not for gaseous PAHs in the present train exposure scenarios, although the limited number of samples available did not allow a statistical analysis [33]. We observed unaltered urinary excretion of PAH metabolites; however, it is unclear if the current exposure contrast was large enough not to be masked by dietary exposure, despite the precautions made. Moreover, the sampling time (morning of the third day) may have not been optimal to detect urinary PAH metabolites. In a controlled wood smoke exposure study, urinary excretion of nine hydroxylated PAHs reached maximal concentrations within $2.3-19.3 \mathrm{~h}$ and returned to background levels $24 \mathrm{~h}$ after exposure [59]. 1-OHP has been used in epidemiological studies, showing positive association with air pollution exposure, although confounding from smoking, occupational PAH exposure and environmental tobacco smoke cannot be ruled out [60]. In contrast, stricter control of other PAH exposures from diet and exclusion of smokers in controlled trials ameliorate confounding.

\section{Conclusions}

The present study showed a consistent reduction in lung function and increased levels of DNA strand breaks after exposure to DE inside passenger carriages of dieselpowered trains, whereas the exposure did not affect the level of oxidatively damaged DNA in PBMCs. The only effect on cardiovascular endpoints was an increased LF in the frequency-domain HRV, suggesting an increase in sympathetic to vagal activity. In agreement with other studies on DE exposure, PAH metabolites were not increased in urine. This may be due to lack of contrast in exposure and lack of sensitivity from the biomarker to detect minor increases in PAH exposure from the background levels of PAH exposure from e.g. diet. Overall, the 3-day exposure to DE in diesel-powered trains was associated with lung and systemic effects.

\section{Methods}

\section{Study participants}

The participants were recruited by registering the study on a human trial web platform (forsoegsperson.dk) and through flyers handed out in the area of Copenhagen, Denmark. We enrolled 33 self-reported healthy, nonasthmatic, without prescribed medication, non-smoking (defined as cessation of smoking at least 1 year before enrollment) and non-pregnant participants living in the Copenhagen region. One subject was excluded after further medical examination and three dropped out before completion. From the 29 participants that completed the study, 4 only participated in two exposure scenarios, failing the participation in the third, for personal reasons. They were included in the analysis since they completed the contrast scenarios. Table 5 presents the general characteristics of the study participants. The age ranged from 21 to 71 years. Fifteen participants had a body mass index (BMI) between 18.6 and $24.8 \mathrm{Kg} / \mathrm{m}^{2}, 10$ between 25.2 and $28.1 \mathrm{Kg} / \mathrm{m}^{2}$ and four between 30.8 and $39.0 \mathrm{Kg} / \mathrm{m}^{2}$. 
Table 5 Characteristics of the study participants at the control measurements (mean $( \pm S D)$ )

\begin{tabular}{llll}
\hline Characteristics & Females $(n=15)$ & Males $(n=14)$ & Total $(n=29)$ \\
\hline Age (years) & $34.7( \pm 14.7)$ & $43.4( \pm 17.6)$ & $38.9( \pm 16.5)$ \\
Height $(\mathrm{cm})$ & $166.6( \pm 4.7)$ & $181.4( \pm 10.1)$ & $173.7( \pm 10.7)$ \\
Weight $(\mathrm{kg})$ & $71.5( \pm 17.5)$ & $81.4( \pm 16.5)$ & $76.3( \pm 17.4)$ \\
BMI $\left(\mathrm{kg} / \mathrm{m}^{2}\right)$ & $25.6( \pm 5.3)$ & $24.7( \pm 3.8)$ & $25.2( \pm 4.6)$ \\
FVC $(\%)$ & $92.7( \pm 15.6)$ & $91.2( \pm 21.5)$ & $92.0( \pm 18.2)$ \\
FEV1 $(\%)$ & $89.4( \pm 16.6)$ & $89.4( \pm 19.2)$ & $89.4( \pm 17.5)$ \\
FEV1/FVC $(\%)$ & $96.3( \pm 7.6)$ & $98.0( \pm 6.5)$ & $97.1( \pm 7.0)$ \\
PEF $(\%)$ & $87.3( \pm 20.4)$ & $85.4( \pm 18.2)$ & $86.4( \pm 19.1)$ \\
\hline
\end{tabular}

SD standard deviation, $B M I$ body mass index, FVC forced vital capacity, FEV1 forced expiratory volume in one second, PEF peak expiratory flow rate. The lung function parameters are presented as the percentage of the predicted value from the general population in the NHANES III survey

\section{Study design}

The study participants travelled 6-h per day during three consecutive days (always on Tuesday, Wednesday and Thursday) inside diesel or electric trains running in the Zealand region, exposure scenarios that have been previously described [33]. The study design was a crossover, repeated measures, where participants served as their own control with a randomized order of exposure inside diesel or electric trains. The diesel scenario exposure was repeated twice, to account for the observed exposure levels and daily variations (four participants only participated in one diesel train exposure). All exposure scenarios were separated by 2 -week periods. The participants were instructed to wear a mask (3M Aura ${ }^{\text {тм }}$ $9320+$, USA) on the way from home to the train station and back home on the exposure days, to prevent other ambient air PM exposure in their transportation activity. At the end of the third day in each scenario, the participants walked for $15 \mathrm{~min}$ from the station to the university facility where the biological samples were collected. They did not use the mask on this walking trip, with the instruments collecting data on exposure. They were also told to avoid consumption of smoked food on the exposure days, and were offered a packed lunch consisting of a sandwich (of humus, tuna or chicken with salad and sauce), fruit, water and a muesli bar every day on the trains. In the morning of the third day in each exposure scenario, the participants gave a urine spot sample, and in the end of the day, we sampled blood and measured lung and cardiovascular function. The participants filled four questionnaires, one for housing characteristics and lifestyle and one for each sampling day about food, activity and medication intake. The volunteers were travelling in groups of 3 to 6 subjects and the entire study was completed within a 7-month period, from May to end of November 2017, with intermission during July.

\section{Exposure assessment}

The study participants carried instruments to monitor UFP (DiscMini and NanoTracer), BC (MicroAeth AE51) and nitrogen oxides (passive samplers Ogawa) as described previously [33]. Daily averages of UFP and BC were determined (without being synchronized and including the data collected when the study participants walked from the station to the university facility where the biological sampling was performed) and averages over the 3 days of each exposure scenario were allocated to each study participant. For nitrogen oxides the accumulated averages exposure were used and also allocated to each study participant. Two measurement days with DiscMini were excluded due to battery failure. A more comprehensive description of exposure data has been published [33], although with a different treatment, as here all the collected data was included in the daily averages, without synchronization start and end times and without eliminating days with delays in the trains.

\section{Lung function}

Lung function was assessed with the EasyOne ${ }^{\mathrm{Tw}}$ Sprirometer 2001 (ndd, Medical technologies, Zurich, Switzerland), in diagnostic mode, measuring FVC, FEV1 and PEF. All measurements were performed after careful instructions and with the participants standing. At least three acceptable manoeuvres were performed to obtain reproducible tracings. The measurements were performed 30-60 min after ending the exposure scenario. Two spirometer results were eliminated due to deficient test quality.

\section{Urine and blood sampling and analysis}

First morning urine samples were delivered by the participants in $120 \mathrm{~mL}$ flasks, aliquoted and stored at $20^{\circ} \mathrm{C}$. Peripheral venous blood samples were collected at the Department of Public Health laboratory facilities in Vacutainer cell preparation tubes $\left(\mathrm{CPT}^{\mathrm{\tau}}{ }^{\mathrm{m}}\right.$, Becton Dickinson A/S, Brøndby, Denmark) for isolation of PBMCs and ethylenediaminetetraacetic acid (EDTA)-coated tubes for plasma preparation. The samples were stored at $-80^{\circ} \mathrm{C}$ in preserving medium, as previously described [34]. It was not possible to collect (and further analyse) 3 samples of blood.

\section{Analysis of biomarkers of exposure in urine}

Levels of 1-OHP, 2-OHF, 1-NAPH and 2-NAPH in urine were measured after solid phase extraction (SPE) using liquid chromatography with tandem mass spectrometry (LC-MS-MS). In brief, $1 \mathrm{ml}$ of urine was mixed with a buffer solution and deconjugated ( $\beta$-glucoronidase, $37^{\circ} \mathrm{C}, 18-20 \mathrm{~h}$ ), after which deuterium-labeled internal standards were added. The samples were loaded onto pre-washed $500 \mathrm{mg}$ C18 SPE-columns (Bond Elut, Agilent Technologies) and subsequently washed using 
$6 \mathrm{ml}$ methanol:water (1:3) and $6 \mathrm{ml}$ water. The SPEcolumns were dried overnight at $55^{\circ} \mathrm{C}$ and eluted with $3 \mathrm{ml}$ methanol. The extract were evaporated to dryness under a gentle stream of nitrogen and reconstituted in $300 \mu \mathrm{L}$ methanol. The extracts were analyzed on an Agilent LC-MS-MS (series 6460) using a Phenomenex C18, $100 \AA, 100 \times 2 \mathrm{~mm}$ column with a gradient of water and methanol. 1-OHP and 2-OHF were quantified using $\mathrm{d}_{9}-1-\mathrm{OHP}$ while $\mathrm{d}_{8}-2-\mathrm{NAPH}$ was used for 1-NAPH and 2-NAPH. The limit of quantification was set to 10 times the signal-to-noise ratio.

All urine concentrations were standardized for diuresis with the concentration of creatinine as previously described [61].

\section{Analysis of biomarkers of effect in blood}

The concentrations of SAA and CRP in plasma were determined by the enzyme-linked immunosorbant assay kits from Invitrogen (CA, USA) and IBL International GMBH (Hamburg, Germany), as previously described [62]. Plasma levels of soluble ICAM-1 and VCAM-1 were measured with BD cytometric bead array system, using Accuri CFlow Plus software (BD Bioscience) as described previously [63]. DNA damage was assessed by levels of DNA strand breaks and Fpg-sensitive sites using the comet assay as described elsewhere [64]. The number of Fpg-sensitive sites was obtained as the difference in scores of parallel slides incubated with and without Fpg (gift from Professor Andrew Collins, University of Oslo, Norway). These scores were transformed to lesions per $10^{6}$ base pairs (bp) by means of a calibration curve based on induction of DNA strand breaks by ionizing radiation $(0-2.5 \mathrm{~Gy})$, which has a known yield. We used an investigator-specific conversion factor of 0.0162 lesions $/ 10^{6} \mathrm{bp}$ per score in $0-100$ range, based on the assumption that an average molecular weight of a DNA bp is $650 \mathrm{Da}$ and one Gy yields 0.29 breaks per $10^{9} \mathrm{Da}$ DNA [65]. Assay control (i.e. cryopreserved samples of THP-1 cells exposed to $5 \mathrm{mM} \mathrm{KBrO}$ for $1 \mathrm{~h}$ at $37^{\circ} \mathrm{C}$ as recommended elsewhere [66]. The assay controls were $1.29 \pm 0.12$ and $0.14 \pm 0.05$ for Fpg-sensitive sites and DNA strand breaks, respectively (mean $\pm \mathrm{SD}, n=10$ ).

\section{Cardiovascular function}

RHI, HRV and augmentation index were measured noninvasively using the portable EndoPAT2000 (Itamar Medical Ltd., Israel), as previously described [35]. The cardiovascular function was the last measurement performed on the study participants $(1-2 \mathrm{~h}$ after end of exposure). Blood pressure was measured with a single measurement using an automatic upper arm blood pressure monitor (Microlife Colson BP 3BXO-A, Widnau, Switzerland), before the peripheral arterial tonometry
(PAT) measurement and in the contralateral arm (control arm), where the blood sample was also taken. Pneumatic sensors were placed on the index fingers to measure pulse volume changes in three test phases: a baseline recording (6-min), a brachial arterial occlusion of one of the arms (5-min), and a post-occlusion recording of the induced reactive hyperemia response (5-min), with reference to the finger probe on the control arm. Additionally, we also measured the vasodilation induced in the control arm after sublingual administration of $0.25 \mathrm{mg}$ of nitroglycerin. The nitroglycerin-induced vasodilation was calculated as the ratio of one-minute average amplitudes of the PAT signal after and before administration, chosen from the 5 min signal at baseline after reactive hyperemia effect and the peak reached during the $15 \mathrm{~min}$ after nitroglycerin treatment. The nitroglycerin was administrated only to 10 participants in both exposure scenarios because of limited medical supervision or a possible history of migraine precluded the administration of nitroglycerin. The EndoPAT software determines the HRV based on $5 \mathrm{~min}$ from the baseline recording, including time domain (SDNN, pNN50 and RMSSD), high (HF) and low frequency (LF) components as well as the ratio LF/HF. It is also from the baseline recording that the augmentation index is determined. All the measurements were done with the participants resting seated, in a quiet room. HRV and LnRHI measurements had 6 missing values.

\section{Statistics}

The results were analysed in a hierarchical approach: first, the effect of diesel exposure as compared to electric trains on all the assessed biomarkers was assessed, and secondly, for biomarkers with statistical significance or border line significance, the associations between air pollution components and biomarkers were assessed. We analysed our results in $\mathrm{R}$ statistical environment by linear mixed-effects model using the package lme4 [67]. As fixed effects we used factorial variables of exposure (diesel/electric) and sex and continuous variable of age. The analyses were adjusted for sex and age because we had missing data. As random effects we used byparticipant intercepts. P-values were obtained with the function glht from multcomp package [68]. We tested the interaction of the order of exposure scenario (electric or diesel) for the relevant biomarkers (with significance or border line significance in the first analysis) and there were no significant interactions. The percent changes were determined by dividing the estimate change with the intercept value and multiplying with 100, except for RHI, augmentation index, SDNN, RMSSD, LF/HF, FVC, ICAM-1, VCAM-1, 2-OHF, 2$\mathrm{NAPH}, \mathrm{SAA}$ and CRP that were natural logarithmically transformed and DNA strand breaks and 1-OHP that 
were transformed with cubic root, and therefor percent changes were obtained from $\left(\operatorname{EXP}_{\text {estimate }}-1\right)^{*} 100$ and $\left(\left(\left((\text { estimate+intercept })^{3}\right.\right.\right.$-intercept $\left.{ }^{3}\right)+$ intercept $) /$ intercept $)$ 1)*100, respectively. The residuals were checked for normality with Shapiro-Wilk test, kurtosis and graphically with histogram and Q-Q plot. Augmentation index, SDNN, RMSSD, LF/HF, FVC, ICAM-1, VCAM-1, 2-OHF, 2$\mathrm{NAPH}, \mathrm{SAA}$, and CRP, showed better distributions after natural logarithmic transformation and DNA strand breaks and 1-OHP after cubic root transformation. Associations that were statistically significant in mixed effects models have been depicted in graphs with the mean of the two measurements for each study participant in the DE scenario. The corresponding univariate analyses of the data in the graphs are mixed effects models without control for age and sex (similar to paired sample t-test).

\begin{abstract}
Abbreviations
BC: Black carbon; BMI: Body mass index; bp: Base pairs; CRP: C-reactive protein; DE: Diesel exhaust; DEP: Diesel exhaust particles; FEV1: Forced expiratory volume in one second; Fpg: Formamidopyrimidine DNA glycosylase; FVC: Forced vital capacity; HF: High frequency component $(0.15-0.4 \mathrm{~Hz}) ; \mathrm{HRV}$ : Heart rate variability; LF: Low frequency component (0.04-0.15 Hz); PAH: Polycyclic aromatic hydrocarbons; PAT: Peripheral arterial tonometry; PBMCs: Peripheral blood mononuclear cells; PEF: Peak expiratory flow; PM: Particulate matter; pNN50: proportion of successive $\mathrm{NN}$ intervals differing by more than 50 milliseconds divided by total number of NN intervals; RHI: Reactive hyperemia index; RMSSD: Root mean square of the successive differences; SAA: Serum amyloid A; SDNN: Standard deviation of all NN intervals; UFP: Ultrafine particles
\end{abstract}

\section{Acknowledgments}

The technical assistance from Annie Jensen, Yuki Tokunaga, Lisbeth Carlsen, Halema Sadia and Ulla Tegner is gratefully acknowledged. A special thanks goes to Danish State Railways for all the logistical support. We are also grateful to the study participants for the considerable time and willingness put into this study.

\section{Authors' contributions \\ MHGA, PM, SL, ATS and UV designed the study. MHGA and PM were responsible for ethical submission and recruitment of participants. MHGA was responsible for study coordination, and acquisition of data on vasculature effects and DNA damage. PM was responsible for the acquisition of data on lung function. SL and RW were responsible for medical supervision and assisted the acquisition of data on independent endothelium vasodilatation. ATS and MR supervised the acquisition of data on inflammatory markers and cell adhesion molecules, respectively. MF was responsible for the acquisition of data on urinary excretion of PAHs metabolites. MHGA, ASF, IKK and SJ were responsible for exposure characterization. MHGA and PM analysed the data. MHGA, PM, RW and SL interpreted the health related data. MHGA drafted the manuscript, which was critically revised by PM, SL, ATS and UV. All authors have read, corrected and approved the manuscript.}

\section{Funding}

The research leading to these results has received funding from Danish Centre for Nanosafety II.

\section{Availability of data and materials}

The datasets analysed during the current study are available from the correspondent author on reasonable request.

\section{Ethics approval and consent to participate}

The Danish Committee on Health Research Ethics of the Capital Region approved the study $(\mathrm{H}-16033227)$. All study participants were given both oral and written information and provided written consent before enrolment.
Consent for publication

Not applicable.

\section{Competing interests}

The authors declare that they have no competing interests.

\section{Author details}

${ }^{1}$ Department of Public Health, Section of Environmental Health, University of Copenhagen, Øster Farimagsgade 5A, DK-1014 Copenhagen K, Denmark.

${ }^{2}$ The National Research Centre for the Working Environment, Lersø Parkalle 105, DK-2100 Copenhagen $\varnothing$, Denmark. ${ }^{3}$ Department of Occupational and Environmental Medicine, Sahlgrenska Academy at University of Gothenburg, Gothenburg, Sweden. ${ }^{4}$ DTU Health Tech., Technical University of Denmark, DK-2800 Kgs. Lyngby, Denmark.

Received: 25 February 2019 Accepted: 16 May 2019

Published online: 11 June 2019

\section{References}

1. Abramesko V, Tartakovsky L. Ultrafine particle air pollution inside dieselpropelled passenger trains. Environ Pollut 2017;226:288-96 https://doi.org/ 10.1016/j.envpol.2017.03.072. https://www.ncbi.nlm.nih.gov/pubmed/ 28390701 https://ac.els-cdn.com/S0269749116325246/1-s2.0-S0269749 1 16325246-main.pdf?_tid=097980ee-3f39-4e09-99a5-0fe71109efc4\&acdnat= 1528733250 661b005c8a5619a21ed635a1031895b9.

2. Jeong CH, Traub A, Evans GJ. Exposure to ultrafine particles and black carbon in diesel-powered commuter trains. Atmospheric Environment. 2017;155:46-52; https://doi.org/10.1016/j.atmosenv.2017.02.015. <Go to |SI>://WOS:000397375300006 https://ac.els-cdn.com/S1352231017300857/1s2.0-S1352231017300857-main.pdf?_tid=18cfc386-bb3f-4d9f-8000c30a676f7f18\&acdnat=1551266651_2d6dcbb87d2f0993300316e5b1b1f171.

3. Laden F, Hart JE, Eschenroeder A, Smith TJ, Garshick E. Historical estimation of diesel exhaust exposure in a cohort study of US railroad workers and lung cancer. Cancer Causes \& Control. 2006;17 7:911-9; https://doi.org/10. 1007/s10552-006-0027-5. <Go to ISI>://WOS:000239040100005 https://link. springer.com/content/pdf/10.1007\%2Fs10552-006-0027-5.pdf.

4. Vermeulen R, Silverman DT, Garshick E, Vlaanderen J, Portengen L, Steenland K. Exposure-Response Estimates for Diesel Engine Exhaust and Lung Cancer Mortality Based on Data from Three Occupational Cohorts. Environmental Health Perspectives. 2014;122 2:172-7; https://doi.org/10. 1289/ehp.1306880. <Go to ISI>:/WOS:000332650500021 https://www.ncbi. nlm.nih.gov/pmc/articles/PMC3915263/pdf/ehp.1306880.pdf.

5. Brook RD, Rajagopalan S, Pope CA, 3rd, Brook JR, Bhatnagar A, Diez-Roux $A V$, et al. Particulate matter air pollution and cardiovascular disease: An update to the scientific statement from the American Heart Association. Circulation. 2010;121 21:2331-78; https://doi.org/10.1161/CIR. 0b013e3181dbece1. https://www.ncbi.n/m.nih.gov/pubmed/20458016.

6. IARC: Diesel and Gasoline Engine Exhausts and Some Nitroarenes. World Health Organization - International Agency for Research on Cancer. 2014; 105:9-699. https://monographs.iarc.fr/wp-content/uploads/2018/06/ mono105.pdf. Accessed 28 May 2019.

7. Stone V, Miller MR, Clift MJD, Elder A, Mills NL, Moller P, et al. Nanomaterials Versus Ambient Ultrafine Particles: An Opportunity to Exchange Toxicology Knowledge. Environ Health Perspect. 2017;125 10:106002; https://doi.org/10. 1289/EHP424. https://www.ncbi.nlm.nih.gov/pubmed/29017987, https:// www.ncbi.nlm.nih.gov/pmc/articles/PMC5933410/pdf/EHP424.pdf.

8. Moller P, Mikkelsen L, Vesterdal LK, Folkmann JK, Forchhammer L, Roursgaard $\mathrm{M}$, et al. Hazard identification of particulate matter on vasomotor dysfunction and progression of atherosclerosis. Crit Rev Toxicol 2011;41 4:339-68; https:// doi.org/10.3109/10408444.2010.533152. https://www.ncbi.nlm.nih.gov/ pubmed/21345153.

9. Barath S, Mills NL, Lundback M, Tornqvist H, Lucking AJ, Langrish JP, et al. Impaired vascular function after exposure to diesel exhaust generated at urban transient running conditions. Part Fibre Toxicol 2010;7:19; https://doi. org/10.1186/1743-8977-7-19. https:/www.ncbi.nlm.nih.gov/pubmed/ 20653945, https://www.ncbi.nlm.nih.gov/pmc/articles/PMC2918524/pdf/ 1743-8977-7-19.pdf.

10. Mills NL, Tornqvist H, Robinson SD, Gonzalez M, Darnley K, MacNee W, et al. Diesel exhaust inhalation causes vascular dysfunction and impaired endogenous fibrinolysis. Circulation. 2005;112 25:3930-6; https://doi.org/ 
10.1161/CIRCULATIONAHA.105.588962. https://www.ncbi.nlm.nih.gov/ pubmed/16365212.

11. Tornqvist H, Mills NL, Gonzalez M, Miller MR, Robinson SD, Megson IL, et al. Persistent endothelial dysfunction in humans after diesel exhaust inhalation. Am J Respir Crit Care Med. 2007;176(4):395-400. https://doi.org/10.1164/ rccm.200606-8720C https://www.ncbi.nlm.nih.gov/pubmed/17446340.

12. Lucking AJ, Lundback M, Barath SL, Mills NL, Sidhu MK, Langrish JP, et al. Particle traps prevent adverse vascular and prothrombotic effects of diesel engine exhaust inhalation in men. Circulation. 2011;123 16:1721-8; https:// doi.org/10.1161/CIRCULATIONAHA.110.987263. https://www.ncbi.nlm.nih. gov/pubmed/21482966.

13. Wauters A, Dreyfuss C, Pochet S, Hendrick P, Berkenboom G, van de Borne $P$, et al. Acute exposure to diesel exhaust impairs nitric oxide-mediated endothelial vasomotor function by increasing endothelial oxidative stress. Hypertension. 2013;62 2:352-8; https://doi.org/10.1161/HYPERTENSIONAHA. 111.00991. https://www.ncbi.nlm.nih.gov/pubmed/23798345.

14. Langrish JP, Unosson J, Bosson J, Barath S, Muala A, Blackwell S, et al. Altered nitric oxide bioavailability contributes to diesel exhaust inhalationinduced cardiovascular dysfunction in man. J Am Heart Assoc. 2013;2 1: e004309; https://doi.org/10.1161/JAHA.112.004309. https://www.ncbi.nlm. nih.gov/pubmed/23525434, https://www.ncbi.nlm.nih.gov/pmc/articles/ PMC3603248/pdf/jah3-2-e004309.pdf.

15. Mills NL, Finlayson AE, Gonzalez MC, Tornqvist H, Barath S, Vink E, et al. Diesel exhaust inhalation does not affect heart rhythm or heart rate variability. Heart. 2011;97 7:544-50; https://doi.org/10.1136/hrt.2010.199042. https://www.ncbi.nlm.nih.gov/pubmed/20962342, https://heart.bmj.com/ content/heartjnl/97/7/544.full.pdf.

16. Vieira JL, Guimaraes GV, de Andre PA, Cruz FD, Saldiva PH, Bocchi EA. Respiratory Filter Reduces the Cardiovascular Effects Associated With Diesel Exhaust Exposure: A Randomized, Prospective, Double-Blind, Controlled Study of Heart Failure: The FILTER-HF Trial. JACC Heart Fail. 2016;4 1:55-64; https://doi.org/10.1016/j.jchf.2015.07.018. https://www.ncbi.nlm.nih.gov/ pubmed/26738952 https://ac.els-cdn.com/S2213177915006575/1-s2.0S2213177915006575-main.pdf?_tid=68398645-a781-4aa5-a1f39978d6af04a1\&acdnat=1541521056_b49da7a482fce5dbcf374f5d1ec26d48.

17. Peretz A, Kaufman JD, Trenga CA, Allen J, Carlsten C, Aulet MR, et al. Effects of diesel exhaust inhalation on heart rate variability in human volunteers. Environ Res 2008;107 2:178-84; https://doi.org/10.1016/j.envres.2008.01.012. https://www.ncbi.nlm.nih.gov/pubmed/18329013 https://www.ncbi.nlm.nih. gov/pmc/articles/PMC2518070/pdf/nihms52690.pdf.

18. Tong H, Rappold AG, Caughey M, Hinderliter AL, Graff DW, Berntsen JH, et al. Cardiovascular effects caused by increasing concentrations of diesel exhaust in middle-aged healthy GSTM1 null human volunteers. Inhal Toxicol 2014;26 6:319-26; https://doi.org/10.3109/08958378.2014.889257. https:// www.ncbi.nlm.nih.gov/pubmed/24655088.

19. Giles LV, Carlsten C, Koehle MS. The effect of pre-exercise diesel exhaust exposure on cycling performance and cardio-respiratory variables. Inhal Toxicol 2012;24 12:783-9; https://doi.org/10.3109/08958378.2012.717649. https://www.ncbi.nlm.nih.gov/pubmed/23033992.

20. Madden MC, Stevens T, Case M, Schmitt M, Diaz-Sanchez D, Bassett M, et al. Diesel exhaust modulates ozone-induced lung function decrements in healthy human volunteers. Part Fibre Toxicol. 2014;11:37; https://doi.org/10. 1186/s12989-014-0037-5. https://www.ncbi.nlm.nih.gov/pubmed/25178924, https://www.ncbi.nlm.nih.gov/pmc/articles/PMC4354281/pdf/s12989-0140037-5.pdf.

21. Nightingale JA, Maggs R, Cullinan P, Donnelly LE, Rogers DF, Kinnersley R, et al. Airway inflammation after controlled exposure to diesel exhaust particulates. Am J Respir Crit Care Med 2000;162 1:161-6; https://doi.org/10.1164/ajrccm. 162.1.9908092. https:/www.ncbi.nlm.nih.gov/pubmed/10903236.

22. Rudell B, Ledin MC, Hammarstrom U, Stjernberg N, Lundback B, Sandstrom T. Effects on symptoms and lung function in humans experimentally exposed to diesel exhaust. Occup Environ Med 1996;53 10:658-62. https://www.ncbi.nlm. nih.gov/pubmed/8943829.

23. Salvi S, Blomberg A, Rudell B, Kelly F, Sandstrom T, Holgate ST, et al. Acute inflammatory responses in the airways and peripheral blood after shortterm exposure to diesel exhaust in healthy human volunteers. Am J Respir Crit Care Med 1999;159 3:702-9; https://doi.org/10.1164/ajrccm.159.3. 9709083. https://www.ncbi.nlm.nih.gov/pubmed/10051240.

24. Stenfors N, Nordenhall C, Salvi SS, Mudway I, Soderberg M, Blomberg A, et al. Different airway inflammatory responses in asthmatic and healthy humans exposed to diesel. Eur Respir J 2004;23 1:82-6. https://www.ncbi. nlm.nih.gov/pubmed/14738236, http://erj.ersjournals.com/content/erj/23/1/ 82.full.pdf.

25. Xu Y, Barregard L, Nielsen J, Gudmundsson A, Wierzbicka A, Axmon A, et al. Effects of diesel exposure on lung function and inflammation biomarkers from airway and peripheral blood of healthy volunteers in a chamber study. Part Fibre Toxicol. 2013;10:60; https://doi.org/10.1186/1743-8977-10-60. https://www.ncbi.n/m.nih.gov/pubmed/24321138, https:/www.ncbinlm.nih. gov/pmc/articles/PMC4029460/pdf/1743-8977-10-60.pdf.

26. Behndig AF, Mudway IS, Brown JL, Stenfors N, Helleday R, Duggan ST, et al. Airway antioxidant and inflammatory responses to diesel exhaust exposure in healthy humans. Eur Respir J 2006;27 2:359-65; https://doi.org/10.1183/ 09031936.06.00136904. https://www.ncbi.nlm.nih.gov/pubmed/16452593, https://erj.ersjournals.com/content/erj/27/2/359.full.pdf.

27. Pourazar J, Mudway IS, Samet JM, Helleday R, Blomberg A, Wilson SJ, et al. Diesel exhaust activates redox-sensitive transcription factors and kinases in human airways. Am J Physiol Lung Cell Mol Physiol 2005;289 5:L724-30; https://doi.org/10.1152/ajplung.00055.2005. https://www.ncbi.nlm.nih.gov/ pubmed/15749742, https://www.physiology.org/doi/pdf/10.1152/ajplung. 00055.2005.

28. Carlsten C, Kaufman JD, Peretz A, Trenga CA, Sheppard L, Sullivan JH. Coagulation markers in healthy human subjects exposed to diesel exhaust. Thromb Res 2007;120 6:849-55; https://doi.org/10.1016/j.thromres.2007.01. 005. https://www.ncbi.nlm.nih.gov/pubmed/17321570, https://www.ncbi. nlm.nih.gov/pmc/articles/PMC2288659/pdf/nihms-32067.pdf.

29. Cliff R, Curran J, Hirota JA, Brauer M, Feldman H, Carlsten C. Effect of diesel exhaust inhalation on blood markers of inflammation and neurotoxicity: a controlled, blinded crossover study. Inhal Toxicol 2016;28 3:145-53; https:// doi.org/10.3109/08958378.2016.1145770. https://www.ncbi.nlm.nih.gov/ pubmed/26915823.

30. Stiegel MA, Pleil JD, Sobus JR, Madden MC. Inflammatory Cytokines and White Blood Cell Counts Response to Environmental Levels of Diesel Exhaust and Ozone Inhalation Exposures. PLoS One. 2016;11 4:e0152458; https://doi.org/10.1371/journal.pone.0152458. https://www.ncbi.nlm.nih.gov/ pubmed/27058360, https://www.ncbi.nlm.nih.gov/pmc/articles/PMC48 25980/pdf/pone.0152458.pdf.

31. Hemmingsen JG, Moller P, Jantzen K, Jonsson BA, Albin M, Wierzbicka A, et al. Controlled exposure to diesel exhaust and traffic noise--effects on oxidative stress and activation in mononuclear blood cells. Mutat Res 2015; 775:66-71; https://doi.org/10.1016/j.mrfmmm.2015.03.009. https://www.ncbi. nlm.nih.gov/pubmed/25898780, https://ac.els-cdn.com/\$0027510715000676/ 1-s2.0-S0027510715000676-main.pdf?_tid=868facd3-8851-4aa9-b370-fec b2b42136a\&acdnat=1541545370_11c0eb5e7ea5259650f8a1 bb1f518a2d.

32. Moller P, Hemmingsen JG, Jensen DM, Danielsen PH, Karottki DG, Jantzen K, et al. Applications of the comet assay in particle toxicology: air pollution and engineered nanomaterials exposure. Mutagenesis. 2015;30 1:67-83; https://doi.org/10.1093/mutage/geu035. https://www.ncbi.nlm.nih.gov/ pubmed/25527730, https://academic.oup.com/mutage/article/30/1/67/ 1000393.

33. Guerra Andersen MH, Johannesson S, Fonseca AS, Clausen PA, Saber AT, Roursgaard $\mathrm{M}$, et al. Exposure to air pollution inside electric and dieselpowered passenger trains. Environmental Science \& Technology; 2019. https://doi.org/10.1021/acs.est.8b06980.

34. Andersen MHG, Saber AT, Clausen PA, Pedersen JE, Lohr M, Kermanizadeh A, et al. Association between polycyclic aromatic hydrocarbon exposure and peripheral blood mononuclear cell DNA damage in human volunteers during fire extinction exercises. Mutagenesis. 2018;33(1):105-15. https:// doi.org/10.1093/mutage/gex021 https://www.ncbi.nlm.nih.gov/pubmed/ 29045708.

35. Andersen MHG, Saber AT, Pedersen PB, Loft S, Hansen AM, Koponen IK, et al. Cardiovascular health effects following exposure of human volunteers during fire extinction exercises. Environ Health. 2017;16 1:96; https://doi.org/ 10.1186/s12940-017-0303-8. https://www.ncbi.nlm.nih.gov/pubmed/28877 717, https://www.ncbi.nlm.nih.gov/pmc/articles/PMC5588677/pdf/12940_ 2017_Article_303.pdf.

36. Giles LV, Tebbutt SJ, Carlsten C, Koehle MS. The effect of low and high-intensity cycling in diesel exhaust on flow-mediated dilation, circulating NOx, endothelin-1 and blood pressure. PLoS One. 2018;13(2):e0192419. https://doi.org/10.1371/ journal.pone.0192419 https:/www.ncbi.nlm.nih.gov/pubmed/29466393.

37. Sack CS, Jansen KL, Cosselman KE, Trenga CA, Stapleton PL, Allen J, et al. Pretreatment with antioxidants augments the acute arterial vasoconstriction caused by diesel exhaust inhalation. Am J Respir Crit Care Med 2016;193 9: 
1000-7; https://doi.org/10.1164/rccm.201506-12470C. https://www.ncbi.nlm. nih.gov/pubmed/26599707, https://www.ncbi.nlm.nih.gov/pmc/articles/ PMC4872652/.

38. Peretz A, Sullivan JH, Leotta DF, Trenga CA, Sands FN, Allen J, et al. Diesel exhaust inhalation elicits acute vasoconstriction in vivo. Environ Health Perspect 2008;116 7:937-42; https://doi.org/10.1289/ehp.11027. https:// www.ncbi.nlm.nih.gov/pubmed/18629317, https://www.ncbi.nlm.nih.gov/ pmc/articles/PMC2453163/pdf/ehp0116-000937.pdf.

39. Brauner EV, Forchhammer L, Moller P, Barregard L, Gunnarsen L, Afshari A, et al. Indoor particles affect vascular function in the aged: an air filtrationbased intervention study. Am J Respir Crit Care Med. 2008;177(4):419-25. https://doi.org/10.1164/rccm.200704-6320C https://www.ncbi.nlm.nih.gov/ pubmed/17932377.

40. Karottki DG, Spilak M, Frederiksen M, Gunnarsen L, Brauner EV, Kolarik B, et al. An indoor air filtration study in homes of elderly: cardiovascular and respiratory effects of exposure to particulate matter. Environ Health. 2013;12: 116. https://doi.org/10.1186/1476-069X-12-116 https://www.ncbi.nlm.nih. gov/pubmed/24373585.

41. Karottki DG, Beko G, Clausen G, Madsen AM, Andersen ZJ, Massling A, et al. Cardiovascular and lung function in relation to outdoor and indoor exposure to fine and ultrafine particulate matter in middle-aged subjects. Environ Int. 2014;73:372-81. https://doi.org/10.1016/j.envint.2014.08.019 https:/www.ncbi. nlm.nih.gov/pubmed/25233101.

42. Olsen Y, Karottki DG, Jensen DM, Beko G, Kjeldsen BU, Clausen G, et al. Vascular and lung function related to ultrafine and fine particles exposure assessed by personal and indoor monitoring: a cross-sectional study. Environ Health 2014;13:112; https://doi.org/10.1186/1476-069X-13-112. https://www. ncbi.nlm.nih.gov/pubmed/25512042, https://www.ncbi.nlm.nih.gov/pmc/ articles/PMC4290094/pdf/12940_2014_Article_813.pdf.

43. Hemmingsen JG, Rissler J, Lykkesfeldt J, Sallsten G, Kristiansen J, Moller PP, et al. Controlled exposure to particulate matter from urban street air is associated with decreased vasodilation and heart rate variability in overweight and older adults. Part Fibre Toxicol. 2015;12:6; https://doi. org/10.1186/s12989-015-0081-9. https:/www.ncbi.nlm.nih.gov/pubmed/ 25890359, https://www.ncbi.nlm.nih.gov/pmc/articles/PMC4374502/pdf/ 12989 2015_Article 81.pdf.

44. Brauner EV, Moller P, Barregard L, Dragsted LO, Glasius M, Wahlin P, et al. Exposure to ambient concentrations of particulate air pollution does not influence vascular function or inflammatory pathways in young healthy individuals. Part Fibre Toxicol. 2008;5:13; https://doi.org/10.1186/1743-89775-13. https://www.ncbi.nlm.nih.gov/pubmed/18837984, https://www.ncbi. nIm.nih.gov/pmc/articles/PMC2579917/pdf/1743-8977-5-13.pdf.

45. Forchhammer L, Moller P, Riddervold IS, Bonlokke J, Massling A, Sigsgaard T, et al. Controlled human wood smoke exposure: oxidative stress, inflammation and microvascular function. Part Fibre Toxicol. 2012;9:7; https://doi.org/10.1186/ 1743-8977-9-7. https:/www.ncbi.nlm.nih.gov/pubmed/22452928, https:/www. ncbi.nlm.nih.gov/pmc/articles/PMC3369202/pdf/1743-8977-9-7.pdf.

46. Moller P, Christophersen DV, Jacobsen NR, Skovmand A, Gouveia AC, Andersen $\mathrm{MH}$, et al. Atherosclerosis and vasomotor dysfunction in arteries of animals after exposure to combustion-derived particulate matter or nanomaterials. Crit Rev Toxicol 2016;46 5:437-76; https://doi. org/10.3109/10408444.2016.1149451. https://www.ncbi.nlm.nih.gov/ pubmed/27028752.

47. Heart rate variability. Standards of measurement, physiological interpretation, and clinical use. Task Force of the European Society of Cardiology and the North American Society of Pacing and Electrophysiology. Eur Heart J. 1996;17 3:354-81. http://www.ncbi.nlm.nih.gov/pubmed/8737210, http://eurheartj. oxfordjournals.org/content/ehj/17/3/354.full.pdf. Accessed 28 May 2019.

48. Brauner EV, Forchhammer L, Moller P, Simonsen J, Glasius M, Wahlin P, et al. Exposure to ultrafine particles from ambient air and oxidative stress-induced DNA damage. Environ Health Perspect 2007;115 8:1177-82; https:/doi.org/ 10.1289/ehp.9984. https://www.ncbi.nlm.nih.gov/pubmed/17687444, https:// www.ncbi.nlm.nih.gov/pmc/articles/PMC1940068/pdf/ehp0115-001177.pdf.

49. Vinzents PS, Moller P, Sorensen M, Knudsen LE, Hertel O, Jensen FP, et al. Personal exposure to ultrafine particles and oxidative DNA damage. Environ Health Perspect 2005;113 11:1485-90; https://doi.org/10.1289/ehp.7562. https://www.ncbi.nlm.nih.gov/pubmed/16263500, https:/www.ncbi.nlm.nih. gov/pmc/articles/PMC1310907/pdf/ehp0113-001485.pdf.

50. Hemmingsen JG, Jantzen $K$, Moller P, Loft S. No oxidative stress or DNA damage in peripheral blood mononuclear cells after exposure to particles from urban street air in overweight elderly. Mutagenesis. 2015;30 5:635-42; https://doi.org/10.1093/mutage/gev027. https:/www.ncbi.nlm.nih.gov/ pubmed/25904586, https://www.ncbi.nlm.nih.gov/pmc/articles/PMC45 40789/pdf/gev027.pdf.

51. Moller P, Daneshvar B, Loft S, Wallin H, Poulsen HE, Autrup H, et al. Oxidative DNA damage in vitamin C-supplemented Guinea pigs after intratracheal instillation of diesel exhaust particles. Toxicol Appl Pharmacol 2003;189 1:39-44. https://www.ncbi.nlm.nih.gov/pubmed/12758058.

52. Kyjovska ZO, Jacobsen NR, Saber AT, Bengtson $\mathrm{S}$, Jackson $\mathrm{P}$, Wallin $\mathrm{H}$, et al. DNA strand breaks, acute phase response and inflammation following pulmonary exposure by instillation to the diesel exhaust particle NIST1650b in mice. Mutagenesis. 2015;30 4:499-507; https://doi.org/10.1093/mutage/ gev009. https://www.ncbi.n/m.nih.gov/pubmed/25771385, https://academic. oup.com/mutage/article/30/4/499/1085542.

53. Nemmar A, Al-Salam S, Beegam S, Yuvaraju P, Hamadi N, Ali BH. In vivo protective effects of Nootkatone against particles-induced lung injury caused by diesel exhaust is mediated via the NF-kappaB pathway. Nutrients. 2018;10 3; https://doi.org/10.3390/nu10030263. https://www.ncbi.nlm.nih. gov/pubmed/29495362, https://res.mdpi.com/nutrients/nutrients-10-00263/ article_deploy/nutrients-10-00263.pdf?filename $=\& a t t a c h m e n t=1$.

54. Risom L, Dybdahl M, Moller P, Wallin H, Haug T, Vogel U, et al. Repeated inhalations of diesel exhaust particles and oxidatively damaged DNA in young oxoguanine DNA glycosylase (OGG1) deficient mice. Free Radic Res 2007;41 2:172-81; https://doi.org/10.1080/10715760601024122. https:/www. ncbi.nlm.nih.gov/pubmed/17364943.

55. Vesterdal LK, Jantzen K, Sheykhzade M, Roursgaard M, Folkmann JK, Loft S, et al. Pulmonary exposure to particles from diesel exhaust, urban dust or single-walled carbon nanotubes and oxidatively damaged DNA and vascular function in apoE(-/-) mice. Nanotoxicology. 2014;8 1:61-71; https://doi.org/10.3109/17435390.2012.750385. https://www.ncbi.nlm.nih. gov/pubmed/23148895, https:/www.tandfonline.com/doi/pdf/10.3109/ 17435390.2012.750385? needAccess=true.

56. Skovmand A, Damiao Gouveia AC, Koponen IK, Moller P, Loft S, Roursgaard M. Lung inflammation and genotoxicity in mice lungs after pulmonary exposure to candle light combustion particles. Toxicol Lett 2017;276:31-8; https://doi.org/10.1016/j.toxlet.2017.04.015. https://www. ncbi.n/m.nih.gov/pubmed/28465192, https://ac.els-cdn.com/S03784274 17301650/1-s2.0-S0378427417301650-main.pdf?_tid=d2ff7d0c-6db3-4aff9f73-717b6df137dd\&acdnat $=1552900370 \_4483956 d f c 69897 f 3 c b c 7245$ $9 f 112535$

57. Moller $\mathrm{P}$, Jensen DM, Christophersen DV, Kermanizadeh A, Jacobsen NR, Hemmingsen JG, et al. Measurement of oxidative damage to DNA in nanomaterial exposed cells and animals. Environ Mol Mutagen 2015;56 2:97-110; https://doi.org/10.1002/em.21899. https://www.ncbi.nlm.nih. gov/pubmed/25196723.

58. Risom L, Dybdahl M, Bornholdt J, Vogel U, Wallin H, Moller P, et al. Oxidative DNA damage and defence gene expression in the mouse lung after shortterm exposure to diesel exhaust particles by inhalation. Carcinogenesis. 2003; 24 11:1847-52; https://doi.org/10.1093/carcin/bgg144. https:/www.ncbi.nlm. nih.gov/pubmed/12919962, https:/academic.oup.com/carcin/article/24/11/ 1847/2390363.

59. Li Z, Trinidad D, Pittman EN, Riley EA, Sjodin A, Dills RL, et al. Urinary polycyclic aromatic hydrocarbon metabolites as biomarkers to woodsmoke exposure results from a controlled exposure study. J. Expo. Sci. Environ. Epidemiol.. 2016. 26 3:241-8; https://doi.org/10.1038/jes.2014.94. <Go to ISI>://WOS: 000374376600002 https:/www.ncbi.nlm.nih.gov/pmc/articles/PMC4532642/ pdf/nihms713881.pdf.

60. Demetriou CA, Raaschou-Nielsen O, Loft S, Moller P, Vermeulen R, Palli D, et al. Biomarkers of ambient air pollution and lung cancer: a systematic review. Occup Environ Med 2012;69 9:619-27; https://doi.org/10.1136/oemed-2011100566. https://www.ncbi.nlm.nih.gov/pubmed/22773658, https://oem.bmj. com/content/oemed/69/9/619.full.pdf.

61. Hansen AM, Mathiesen L, Pedersen M, Knudsen LE. Urinary 1-hydroxypyrene (1-HP) in environmental and occupational studies--a review. Int J Hyg Environ Health 2008;211 5-6:471-503; https://doi.org/10.1016/j.jiheh.2007.09.012. https://www.ncbi.nlm.nih.gov/pubmed/18222724.

62. Madsen AM, Thilsing T, Baelum J, Garde AH, Vogel U. Occupational exposure levels of bioaerosol components are associated with serum levels of the acute phase protein serum amyloid a in greenhouse workers. Environ Health 2016; 15:9; https://doi.org/10.1186/s12940-016-0090-7. https://www.ncbi.nlm.nih.gov/ pubmed/26792395, https://www.ncbi.nlm.nih.gov/pmc/articles/PMC4719338/ pdf/12940_2016_Article_90.pdf. 
63. Jensen A, Karottki DG, Christensen JM, Bonlokke JH, Sigsgaard T, Glasius M et al. Biomarkers of oxidative stress and inflammation after wood smoke exposure in a reconstructed Viking age house. Environ Mol Mutagen 2014; 55 8:652-61; https://doi.org/10.1002/em.21877. https:/www.ncbi.nlm.nih. gov/pubmed/24889798.

64. Andersen MHG, Saber AT, Pedersen JE, Pedersen PB, Clausen PA, Lohr M, et al. Assessment of polycyclic aromatic hydrocarbon exposure, lung function systemic inflammation, and genotoxicity in peripheral blood mononuclear cells from firefighters before and after a work shift. Environ Mol Mutagen 2018; https://doi.org/10.1002/em.22193. https:/www.ncbi.nlm.nih.gov/pubmed/ 29761929, https://onlinelibrary.wiley.com/doi/pdf/10.1002/em.22193.

65. Forchhammer L, Johansson C, Loft S, Moller L, Godschalk RW, Langie SA, et al. Variation in the measurement of DNA damage by comet assay measured by the ECVAG inter-laboratory validation trial. Mutagenesis. 2010;25 2:11323; https://doi.org/10.1093/mutage/gep048. https://www.ncbi.nlm.nih.gov/ pubmed/19910383, https:/academic.oup.com/mutage/article/25/2/113/ 1020210.

66. Moller P, Jantzen K, Lohr M, Andersen MH, Jensen DM, Roursgaard M, et al. Searching for assay controls for the Fpg- and hOGG1-modified comet assay. Mutagenesis. 2018;33 1:9-19; https://doi.org/10.1093/mutage/gex015. https://www.ncbi.nlm.nih.gov/pubmed/28992346, https://academic.oup. com/mutage/article-abstract/33/1/9/4158668?redirectedFrom=fulltext.

67. Bates D, Machler M, Bolker BM, Walker SC. Fitting Linear Mixed-Effects Models Using Ime4. Journal of Statistical Software. 2015;67(1):1-48 <Go to $|S|>: / /$ WOS:000365981400001.

68. Hothorn T, Bretz F, Westfall P. Simultaneous inference in general parametric models. Biom J 2008;50 3:346-63; https://doi.org/10.1002/bimj.200810425. https://www.ncbi.nlm.nih.gov/pubmed/18481363, https:/onlinelibrary.wiley. com/doi/abs/10.1002/bimj.200810425.

\section{Publisher's Note}

Springer Nature remains neutral with regard to jurisdictional claims in published maps and institutional affiliations.

Ready to submit your research? Choose BMC and benefit from:

- fast, convenient online submission

- thorough peer review by experienced researchers in your field

- rapid publication on acceptance

- support for research data, including large and complex data types

- gold Open Access which fosters wider collaboration and increased citations

- maximum visibility for your research: over $100 \mathrm{M}$ website views per year

At $\mathrm{BMC}$, research is always in progress.

Learn more biomedcentral.com/submissions 